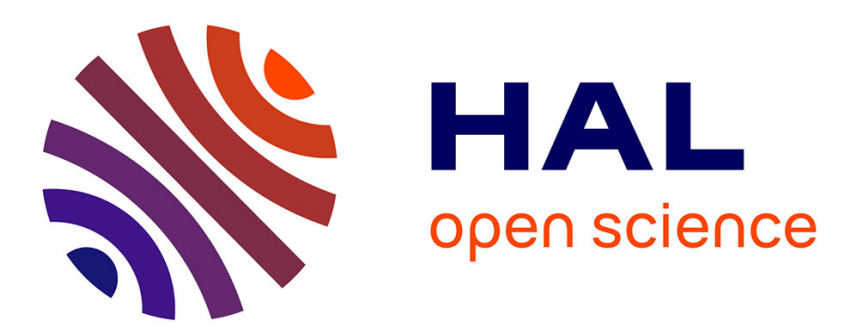

\title{
A European morpho-functional classification of humus forms
}

Augusto Zanella, Bernard Jabiol, Jean-François Ponge, Giacomo Sartori, Rein

de Waal, Bas van Delft, Ulfert Graefe, Nathalie Cools, Klaus Katzensteiner, Herbert Hager, et al.

\section{To cite this version:}

Augusto Zanella, Bernard Jabiol, Jean-François Ponge, Giacomo Sartori, Rein de Waal, et al.. A European morpho-functional classification of humus forms. Geoderma, 2011, 164 (3-4), pp.138-145. 10.1016/j.geoderma.2011.05.016 . hal-00611772

\section{HAL Id: hal-00611772 https://hal.science/hal-00611772}

Submitted on 27 Jul 2011

HAL is a multi-disciplinary open access archive for the deposit and dissemination of scientific research documents, whether they are published or not. The documents may come from teaching and research institutions in France or abroad, or from public or private research centers.
L'archive ouverte pluridisciplinaire $\mathbf{H A L}$, est destinée au dépôt et à la diffusion de documents scientifiques de niveau recherche, publiés ou non, émanant des établissements d'enseignement et de recherche français ou étrangers, des laboratoires publics ou privés. 


\title{
A European morpho-functional classification of humus forms
}

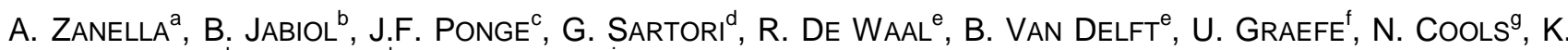 \\ KATZENSTEINER ${ }^{\text {h }}$ H. HAGER ${ }^{h}$ \& M. ENGLISCH \\ a University of Padua, Department of Land, Environment, Agriculture and Forestry, Viale dell'Università 16, 35020 Legnaro, \\ Italy, ' AgroParisTech, ENGREF-LERFOB, 14 rue Girardet, 54042 Nancy, France, 'Museum National d'Histoire Naturelle, \\ CNRS UMR 7179, 4 avenue du Petit Château, 91800 Brunoy, France, dMuseo Tridentino di Scienze Naturali, Via \\ Calepina 14, 38100 Trento, Italy, ${ }^{\mathrm{e}}$ Alterra, Centre for Ecosystem Studies, Environmental Sciences Group, Wageningen \\ University and Research Centre, P.O. Box 47, 6700 AA Wageningen, The Netherlands, 'Institut für Angewandte \\ Bodenbiologie GmbH, Sodenkamp 62, 22337 Hamburg, Germany, ${ }^{9}$ Research Institute for Nature and Forest, Gaverstraat \\ 4, 9500 Geraardsbergen, Belgium, hinstitute of Forest Ecology, Department of Forest and Soil Sciences, University of \\ Natural Resources and Applied Life Sciences (BOKU) Vienna, Peter Jordanstr. 82, 1190 Vienna, Austria, 'Federal \\ Research and Training Centre for Forests, Natural Hazards and Landscape, Seckendorff-Gudent-Weg 8, 1131 Vienna, \\ Austria.
}

Corresponding author: Augusto Zanella. University of Padua, Department of Land, Environment, Agriculture and Forestry, Viale dell'Università 16, 35020 Legnaro (PD), Italy. Tel.: +39 0498272755; fax: +39 0498272686, E-mail: augusto.zanella@unipd.it

\begin{abstract}
In Europe an abundance of humus taxonomies exists starting with early approaches in the late 19th century. Frequently used in an international context, they do not cover all site conditions in the European area. Although having basic concepts and general lines, the European (and North American, Canadian) classification systems differ in important parameters used for the description and classification of humus forms. These discrepancies result in incongruities, so they require adjustments when exchanging partially compatible soil data, even between nearby countries. In 2003,26 European specialists in humus forms met in Trento (Italy) and decided to formulate rules of classification based on morphogenetic descriptions and diagnostic horizons, adapted to European ecological conditions. Taking into account old and new European and North American systems of humus forms classification, six main references (Anmoor, Mull, Moder Mor, Amphi and Tangel) were defined, each of them further divided into more detailed categories. This inventory assigned a strong discriminatory power to the action of soil animals. Both semiterrestrial (anoxic) and terrestrial (aerated) topsoils were classified. Descriptors of diagnostic horizons were conceived in accordance with recent international soil classifications. Assigning an 'ecological value' to each main humus form along a gradient from biologically active forms, degrading and incorporating all organic remains, to those characterized by the accumulation of poorly transformed organic matter, this European system of classification avoids a strong hierarchical structure and allows a flexible approach open to additional ecological contributions and renditions.
\end{abstract}




\section{Introduction}

\subsection{Basic concepts}

The humus form is the part of the topsoil that is strongly influenced by organic matter and coincides with the sequence of organic and underlying organo-mineral horizons. During the $19^{\text {th }}$ century, scientists noticed that the type and rate of decomposition of these organic components, as well as the incorporation of organic matter (OM) in mineral horizons, vary according to forest type (review in Jabiol et al., 2005). These observations led Müller $(1879,1884,1887,1889)$ to define three 'humus forms', named Muld (later becoming Mull), Mor and Mullartiger Torf (now Moder), characterized by their climatic, geological and biological conditions of formation in Danish beech forests. From the outset it was evident to Müller that the humus form corresponds to the "expression of life" within the topsoil. Many authors contributed to the development of a classification system of humus forms based on the key role of living components in the topsoil. The most prominent contributions are those of Hesselman (1926), Hartmann (1944), Kubiëna (1953), Babel (1971) and Delecour (1983).

All these concepts still form the basis of modern classifications of humus forms (Green et al., 1993; AFES, 1995; Baize \& Girard, 1998; Nestroy et al., 2000; Zanella et al., 2001; Brunner et al., 2002; Baritz, 2003; AK Humusformen, 2004; Zanella et al., 2006; Jabiol et al., 2007; Van Delft et al., 2007; AFES, 2009; Jabiol et al., 2009). Although Canadian (British Columbian) and French classification systems are frequently used in an international context, none of them covers site and climate conditions worldwide, not even all European forest ecosystems. Moreover, the new national classification systems differ according to the parameters used for describing and classifying humus forms as well as for scaling diagnostic parameters (Schoeneberger et al., 2002; Baritz, 2003). Similar designations of humus forms often have different contents.

\subsection{Harmonization purposes}

With harmonization purposes in mind, a wide range of European specialists met in Trento (Italy) in 2003 and formed a European Humus Group with the aim of improving the compatibility of established national systems of classification and setting out a unified European reference for humus forms. The present synthesis was elaborated during the course of four plenary field sessions held in Alpine (Trento 2003, Vienna 2004, San Vito di Cadore 2005) and Mediterranean (Cagliari 2007) ecosystems. In these workshops, the place of lesser known terrestrial humus forms such as Tangel and Amphi and that of semi-terrestrial humus forms were discussed and included in a new classification (Jabiol et al., 2004; Zanella et al., 2009). In the meantime the key of humus forms was also tested by non-specialists in order to improve it and to discard interpretative drawbacks. In the future, the proposed humus form classification will also be included in a worldwide topsoil characterization that is currently being prepared (Broll et al., 2006).

This paper focuses on the aims and principles of the proposed European classification, details and keys being found in a more complete review available at:

http://hal.archives-ouvertes.fr/docs/00/56/17/95/PDF/Humus Forms ERB 3101 2011.pdf

\section{Morpho-functional bases and references for the classification}

At the end of the first meeting of the Humus group (Trento, Italy, 2003), after numerous field tests and discussions, the members of the group agreed on a very important "principle of classification": the classification process has to take into consideration only references (objects observable in the field or complexes of objects) which show an evident "morphofunctional" shape or core. This means that: a) each reference must be recognisable thanks to its particular and characteristic morphology; b) this morphology must be easily detectable to the naked eye or with a 5-10X magnifying hand lens; c) the function of the reference within the soil system has to be well expressed, identifiable or reasonably assumed to be possible.

The references of the classification are arranged in a nested way: basilar components (from intact leaves/needles until more or less degraded remains, animal droppings, roots, mineral particles...) are arranged in diagnostic horizons (discernable supra-structures of basilar components), themselves arranged in humus forms (evident well structured sets of diagnostic horizons). The detection in the field of the basilar components allows the identification of the diagnostic horizons, and the order and thickness of these horizons in the topsoil allow the humus forms to be classified. The basilar components are presented below, while the diagnostic horizons and humus forms are described in sections 3 and 4 .

\subsection{Recognizable remains vs. humic component}

Fresh litter is generally made up of $100 \%$ recognizable remains. They correspond to leaves, needles, roots, bark, twig and wood pieces, fragmented or not, whose original organs are recognizable to the naked eye or with a 5-10 X magnifying hand lens. Depending on local climatic and biological conditions, this organic material will be rapidly or slowly transformed into humic component as a consequence of biological activity in the site (Fig. 1a). The humic component is formed by small and non-recognizable organic remains and/or grains of organic or organo-mineral matter, mostly comprised of animal droppings of different sizes. The original plant/animal organs which form the litter and generate smaller particles (free or incorporated in animal droppings) are not recognizable to the naked eye or with a 5-10 X magnifying hand lens.

\subsection{Micro-, meso-, macroaggregates and mineral component}

The humic component often takes the shape of soil aggregates, which are visible to the naked eye or with a magnifying hand lens and are classed in three types of structure, called micro-, meso- and macrostructures (Fig. 2). A level of structure finer than $1 \mathrm{~mm}$ cannot be detected by the naked eye (using a $10 \mathrm{X}$ magnifying lens, the limit is $0.1 \mathrm{~mm}$ ). These 
very fine granular structures could be comprised of small arthropod or enchytraeid droppings (purely organic or mixed organic and mineral), layering or juxtaposed to mineral particles. Bound mineral particles visible within the humic component and strongly fixed in organo-mineral well-amalgamated aggregates (peds) are categorized as part of the humic component. On the contrary, mineral particles of different sizes, free or very weakly bound to the humic component and visible to the naked eye or with a 5-10 X magnifying hand lens, are considered as other soil parts collectively named mineral component.

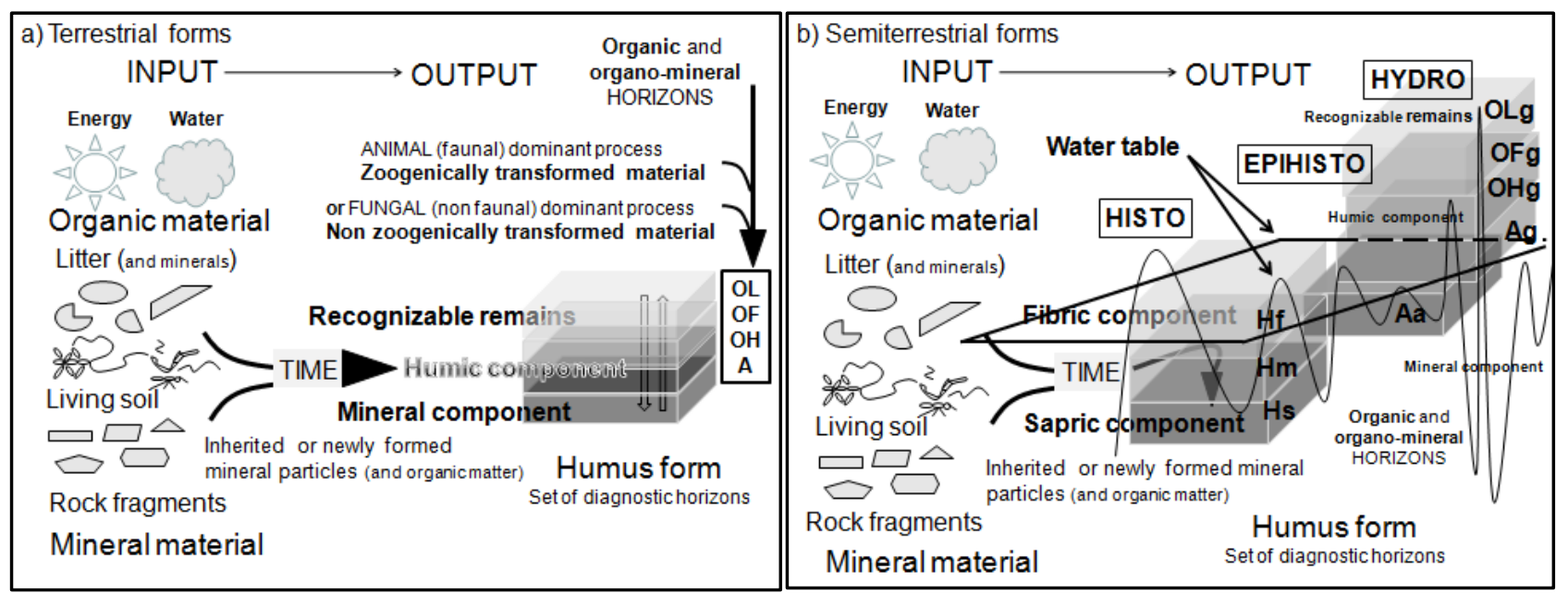

Fig. 1. Vocabulary and dynamic formation of an example topsoil in a) Terrestrial and b) Semiterrestrial conditions. Above- and below-ground processes are similar. On one side "decomposition" or "weathering", from leaves to molecules or from minerals to elements; on the other side "composition", from mineral elements, organic molecules and water to biological structures (trees, animals...), neoformation clay, humic component, soil sub-units (peds). In aerated soils (terrestrial soils), thick organic horizons form on cold, acid and dry soils; in water saturated soils (semiterrestrial conditions), asphyxia delays biodegradation and the thickness of the organic horizons depends on the length of the saturation period.

\subsection{Zoogenically vs. non-zoogenically transformed material}

Zoogenically transformed material is made of recognizable remains and humic components processed by animals, i.e. leaves, needles and other plant residues more or less degraded by soil animals, mixed with animal droppings. A finely powdered and/or granular structure (less than $1 \mathrm{~mm}$ ) is typical of the terminal stage of faunal attack in an organic horizon (Fig. 1a). At this last level of biotransformation, the horizon matrix is essentially comprised of organic animal droppings of varying size (droppings of epigeic earthworms, of macroarthropods such as millipedes, woodlice and insect larvae, of microarthropods such as mites and springtails and of enchytraeids dominate). Within organo-mineral horizons, animal activity leads to different types of $A$ horizons, depending on the ability of animals to dig into the mineral soil and to thoroughly mix organic and mineral matter. Zoogenically transformed material may be active (currently inhabited by living animals, freshly transformed, with recent droppings, bite marks or tunnels) or inactive (without living animals or recent signs of animal activity, for 1-2 years or more).

Non-zoogenically transformed material is made of recognizable remains and humic components processed by fungi or other non-faunal processes, i.e. leaves, needles and other plant residues more or less fragmented and transformed into fibrous matter by fungi. Recognizable recent animal droppings are absent or not detectable in the mass by the naked eye. Fungal hyphae can be recognized as white, brown, black or yellow strands permeating the organic or organo-mineral substrates. Traces of animal activity (droppings, old bite marks, mucus) may sometimes be detectable but are always marginal. In the last stage of biodegradation of an organic horizon, non-zoogenic substances may essentially be composed of dry, brown plant residues more or less powdered or in tiny fragments. Non-zoogenically transformed material is in any case inactive material that exhibits low biological activity.

\subsection{Fibric vs. sapric components of histic (peat) horizons}

The fibric component of peat is made of non-decomposed or very weakly decomposed hygrophilous plant remains like sphagnum mosses, sedges, rushes, reeds... It is comprised of whole plants, parts of them and/or separate plant organs (leaves, needles, twigs, wood, roots..., Fig. 1b). The sapric component is made of homogeneous dark organic or organomineral matter comprised of well decomposed plant remains pure or partly mixed with mineral particles. Plant structures are not visible to the naked eye or with a 5-10 X magnifying hand lens. Animal droppings are possible in periodically drained horizons and can be abundant in drained peats. 


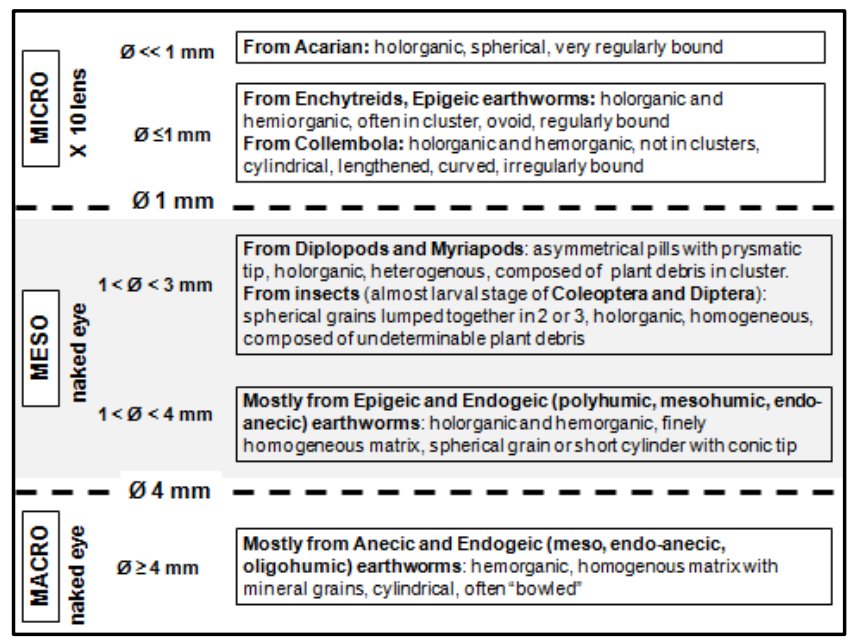

Fig. 2. Field classification of droppings of the most common groups of pedofauna (modified from Galvan et al., 2005). Droppings are divided into three categories, named micro $(<=1 \mathrm{~mm})$, meso $(1-4 \mathrm{~mm})$ and macro $(>4 \mathrm{~mm})$, corresponding to the abovementioned zoogenic $A$ horizons ( $m i A, m e A$ and $m a A$ ).

\section{Diagnostic horizons}

A minimum thickness of horizons for description, diagnosis and sampling purposes has been established at $3 \mathrm{~mm}$. Below this threshold, a horizon is considered discontinuous if clearly in patches or absent if indiscernible from other neighbouring horizons. The vagueness of transitions between organic and organo-mineral horizons (or mineral ones, in the absence of an organo-mineral horizon) is an important diagnostic character. Three types of transition have been adopted: very sharp transition within less than 3 $\mathrm{mm}$, sharp transition between 3 and $5 \mathrm{~mm}$ and diffuse transition if over more than $5 \mathrm{~mm}$.

\subsection{Diagnostic horizons of Terrestrial humus forms (aerated topsoils)}

Two main types of diagnostic horizons ( $\mathrm{O}$ for organic and $\mathrm{A}$ for organo-mineral) have been distinguished in aerated soils (never, or for few days per year, submerged and/or water-saturated). Roots excluded, following the rate of recognizable remains and humic components, organic horizons of aerated soils have been grouped in three diagnostic horizons, reminiscent of the seminal work of Hesselmann (1926), called OL, OF and OH. Suffixes are used to designate specific types of organic horizons then detailed into subtypes, e.g. zoogenic and non-zoogenic OF horizons. At present, the names and suffixes of these organic horizons are not fully in line with IUSS Working Group WRB (2007) or Soil Survey Staff (2010) proposals. However, the following approximated correspondence may be established with the U.S. Soil Taxonomy: $\mathrm{OL}=\mathrm{Oi} ; \mathrm{OF}=\mathrm{Oe} ; \mathrm{OH}=\mathrm{Oa}$. A general attempt to harmonize vocabulary and procedures for topsoil classification is in progress (Broll et al., 2006).

\subsubsection{Organic horizons}

The OL horizon is characterized by the accumulation of mainly leaves/needles, twigs and woody materials, most of the original plant organs being easily discernible to the naked eye. The humic component amounts to less than $10 \%$ by volume; recognizable remains $90 \%$ and more, up to $100 \%$ in non-decomposed litter (Fig. 3). Suffixes characterize neither fragmented nor transformed/discoloured leaves and/or needles (OLn), and slightly altered, discoloured, bleached, softened up, glued, matted, skeletonized, sometimes only slightly fragmented leaves and/or needles (OLv).

The OF horizon is characterized by the accumulation of partly decomposed litter, mainly from transformed leaves/needles, twigs and woody materials, but without any entire plant organ. The proportion of humic component is $10 \%$ to $70 \%$ by volume (Fig. 3). Depending on humus form, decomposition is mainly accomplished by soil fauna (OFzo) or cellulose-lignin decomposing fungi (OFnoz). Slow decomposition is revealed by a partly decomposed matted layer, permeated by hyphae. The $\mathbf{O H}$ horizon is characterized by an accumulation of zoogenically transformed material, i.e. black, grey-brown, brown, reddish-brown well-decomposed litter, mainly comprised of aged animal droppings. A large part of the original structures and materials are not discernible, the humic component amounting to more than $70 \%$ by volume (Fig. 3). The OH horizon differs from the OF horizon by a more advanced transformation (fragmentation, humification, ...) due to the action of soil organisms.

The weight (\%) of organic carbon in dry samples of organic horizons without living roots has to be at least $20 \%$ by mass (Method: element analyzer, ISO 10694, 1995).

\subsubsection{Organo-mineral horizons}

The different diagnostic $\mathbf{A}$ horizons are identified in the field by observing the soil mass with the naked eye or with a 5-10X magnifying hand lens (Fig. 2), assessing structure and consistence (Soil Survey Division Staff, 1993; FAO, 2006) and measuring the acidity (pHwater) according to ISO 10390 (1995). In the fraction $\varnothing<2 \mathrm{~mm}$ of the A horizon, the organic carbon has to be less than $20 \%$ by mass following IUSS Working Group WRB (2007). Five diagnostic A horizons may be distinguished: three zoogenic A horizons (biomacrostructured, maA; biomesostructured, meA; biomicrostructured, miA) and two non-zoogenic A horizons (single grain, sgA; massive, msA). 


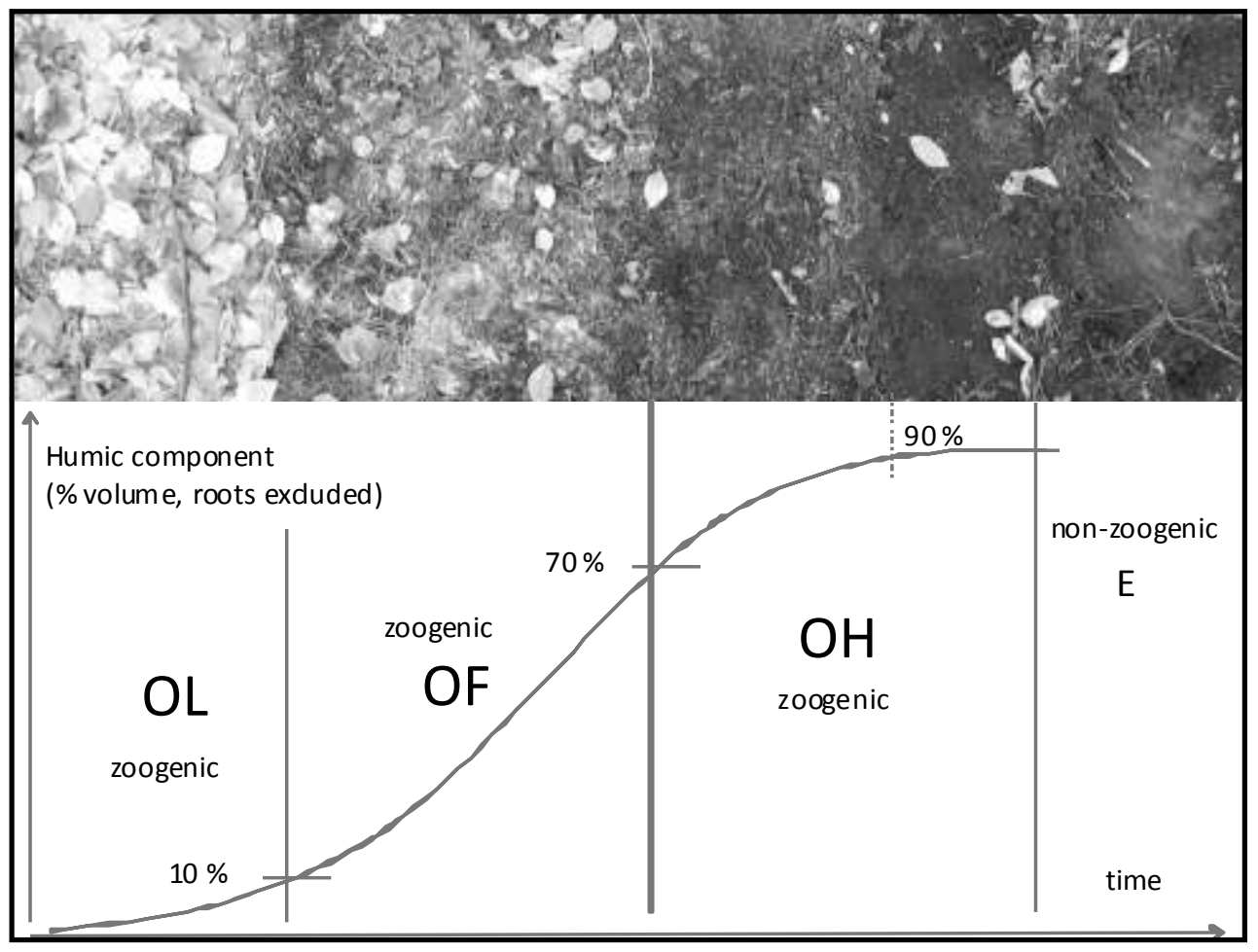

Fig. 3. The biological transformation of litter as observed in the field. On the left the superficial layer is made of still intact leaves $(O L$ horizon); removing this layer manually, the biological process of litter degradation clearly appears when the amount of humic component surpasses $10 \%$ of the observed volume of the organic substrate: the new layer is named OF horizon (centre of the figure); digging this horizon carefully, the amount of humic component progressively rises and when it surpasses $70 \%$ of the volume, the organic substrate becomes an $\mathrm{OH}$ horizon (right of the figure). The building of the humus form is the result of this space/time process of bio-transformation of the litter in different environments.

\subsection{Diagnostic horizons of Semiterrestrial humus forms (waterlogged topsoils)}

\subsubsection{Histic horizons}

Histic horizons are submerged and/or water-saturated for a prolonged period of the year (usually more than 6 months).

\subsubsection{Organic horizons}

Following the rate of fibric and sapric components, histic organic horizons ( $\mathrm{H}$ horizons) have been divided in three diagnostic horizons: $\mathrm{Hf}, \mathrm{Hm}$ and $\mathrm{Hs}$ (Fig. 4). Though named differently ( $\mathrm{Hf}=\mathrm{Hi}$ or Oi; $\mathrm{Hm}=\mathrm{He}$ or Oe; $\mathrm{Hs}=\mathrm{Ha}$ or $\mathrm{Oa}$ or $\mathrm{L}$ ), these horizons are roughly the same as those used in the main international soil taxonomies (IUSS Working Group WRB, 2007; AFES, 2009; Soil Survey Staff, 2010) for describing peat soils. Carbon content has to be $20 \%$ or more (approximately $35-40 \%$ organic matter) by weight in dry samples, without living roots (Method: element analyzer, ISO 10694, 1995).

The $\mathrm{Hf}$ horizon consists almost entirely of practically unchanged plant remains (fibric component $\geq 90 \%$, sapric component $<10 \%$ of horizon volume).

The $\mathrm{Hm}$ horizon consists of half decomposed organic material not fitting the definition of fibric (Hf) or sapric (Hs) horizons (fibric component $10 \%$ to $70 \%$, sapric component $90 \%$ to $30 \%$ by volume).

The Hs horizon is in an advanced stage of decomposition (sapric content $\geq 70 \%$ of the horizon volume; fibric component less than $30 \%$ ). Suffixes are used for Hs horizons according to high activity of soil animals (Fig. 4), especially earthworms (Hszo), massive structure with low activity of soil animals (Hsnoz), and high percentage of mineral particles (Hsl). Sapric horizons of brook valley systems and around wells have mostly a higher amount of mineral fraction than those in fens and/or bogs. Although at first sight quite similar, the horizons can differ in structure, $\mathrm{pH}$, nutrient content and base saturation due to differences in water quality, vegetation and soil organisms.

\subsubsection{Organo-mineral horizons}

Named Aa (from A horizon and anmoor), the histic organo-mineral horizon is mostly built by microorganisms (actinomycetes), dark coloured, with plastic and massive structure, either high or low base-saturated. Earthworms may be abundant during better aerated periods, but the typical structure of their droppings is rapidly destroyed by water immersion and permanence. Carbon content is between 7 and $20 \%$ by weight, in dry samples without living roots (Method: element analyser, ISO 10694, 1995). 


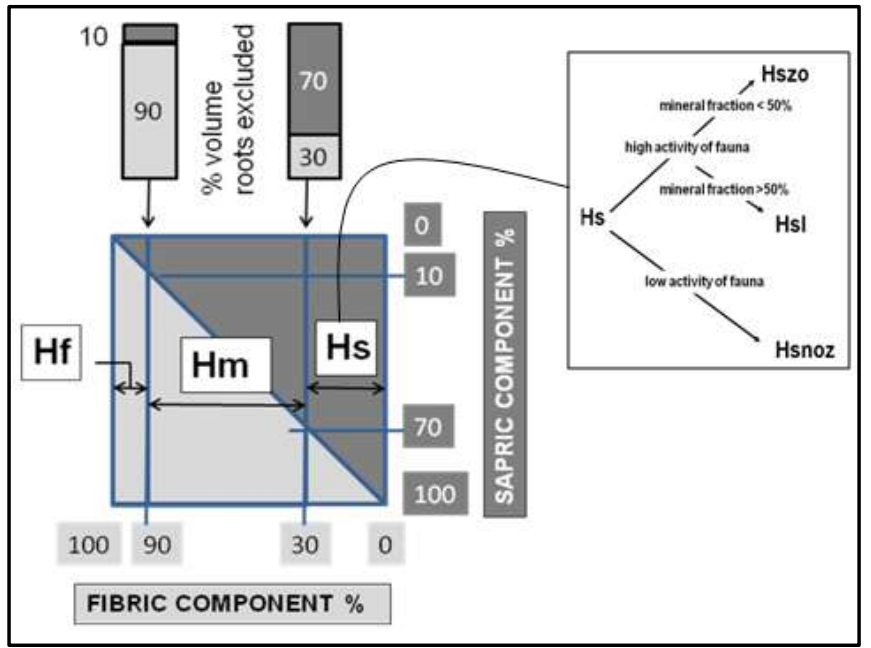

Fig. 4. Left: Hf, $\mathrm{Hm}$ and $\mathrm{Hs}$ horizons in graphical definition; right: types of Hs horizons (zoogenic typic and limi; non-zoogenic).

\subsubsection{Hydromorphic horizons}

Hydromorphic horizons are submerged and/or watersaturated for a non-prolonged period of the year (more than a few days but less than 6 months).

\subsubsection{Organic horizons}

Formed under non-prolonged water saturation, hydromorphic organic horizons are periodically watersaturated and show the effects of temporary anoxia. On the model of terrestrial horizons, they are named OLg, OFg and OHg: the humic component is less than $10 \%$ in volume (roots excluded) in OLg, between 10 and $70 \%$ in OFg and more than $70 \%$ in OHg. The suffix letter "g" indicates the presence of hydromorphic properties: plant remains become dark, glued together and are often coloured along the venation (more evident than usual) of leaves by black particles of humic component deposited by water during the period of immersion. The humic component is often dark grey or black, massive and plastic, and may be structured in animal droppings during aerated periods.

\subsubsection{Organo-mineral horizons}

Hydromorphic organo-mineral horizons show evident effects of temporary anoxia such as Fe-mottling and oxidation/reduction colours (orange-red splashes within grey to bluish-grey mass), cover at least 1/3 of the surface of the horizon profile; carbon content is generally less than $7 \%$ by weight. All terrestrial A horizons showing hydromorphic properties become hydromorphic organo-mineral horizons. In this case, a letter " $\mathrm{g}$ ", meaning hydromorphic properties, is added to their corresponding terrestrial code: $\mathbf{m a A g}, \mathbf{m e A g}, \mathbf{m i A g}, \mathbf{m s A g}, \mathbf{s g A g}$.

If carbon content is higher than $7 \%$ by weight, similarities with Aa or Hs are possible. However, the structure of maAg or meAg horizons, mostly due to anecic and endogeic earthworms, and although partially destroyed by water, never becomes completely plastic and massive as in the Aa horizon; carbon content of miAg, msAg and sgAg never reaches $20 \%$, which is the case in every kind of Hs horizon.

\section{Humus forms classification}

The European classification of humus forms is based on the sequence and morphological characteristics, including evidence of biological activity, of organic and/or organo-mineral horizons observed and described in the field (forests, grasslands, pastures and wetland areas, to the exclusion of croplands). In some cases a few basic chemical data (pH, organic carbon content) are required. A complete set of diagnostic organic and organo-mineral horizons, which are mutually exclusive, is defined. The classification keys use diagnostic horizons and other complementary topsoil or environmental data.

The first dichotomy of the classification separates never saturated from saturated (submerged) humus forms (Fig. 5). Within each group of the Terrestrial compartment (Terroforms, Entiforms and Paraforms) and within each group of Hydroforms of the Semiterrestrial compartment (Hydro-, Epihisto- and Histo-forms), the same five 'biological types' are identified on a morpho-functional basis: Mull, Amphi, Moder, Tangel and Mor (Fig. 6). Within Histoforms and Epihistoforms, the Tangel biological type is not present, but a characteristic 'soil moisture regime' generates the Anmoor biological type. These 'biological types', or main references, can be considered as the highest taxonomic levels of the classification (Fig. 6). For Terroforms and Histoforms, the most important and best-known groups of humus forms, a second level of classification has been created. Here, each unit of the main level (Mull, Moder, ...) is split in two or more biological sub-types or secondary references (i.e. Eumull, Mesomull; Hemimoder, Dysmoder...).

\subsection{Terrestrial humus forms}

Terrestrial humus forms correspond to the topsoil never or for only a few days per year submerged and/or watersaturated. They are subdivided into Terroforms, Entiforms and Paraforms, the diagnostic criteria of which are briefly summarized in Figures 5 and 6.

\subsubsection{Terroforms}

The five main references (Mull, Moder, Amphi, Mor and Tangel) of Terroforms are identified and described thanks to diagnostic features. Each main reference is in turn subdivided into secondary references according to quantitative differences in the thickness of constitutive horizons (Fig. 7). 

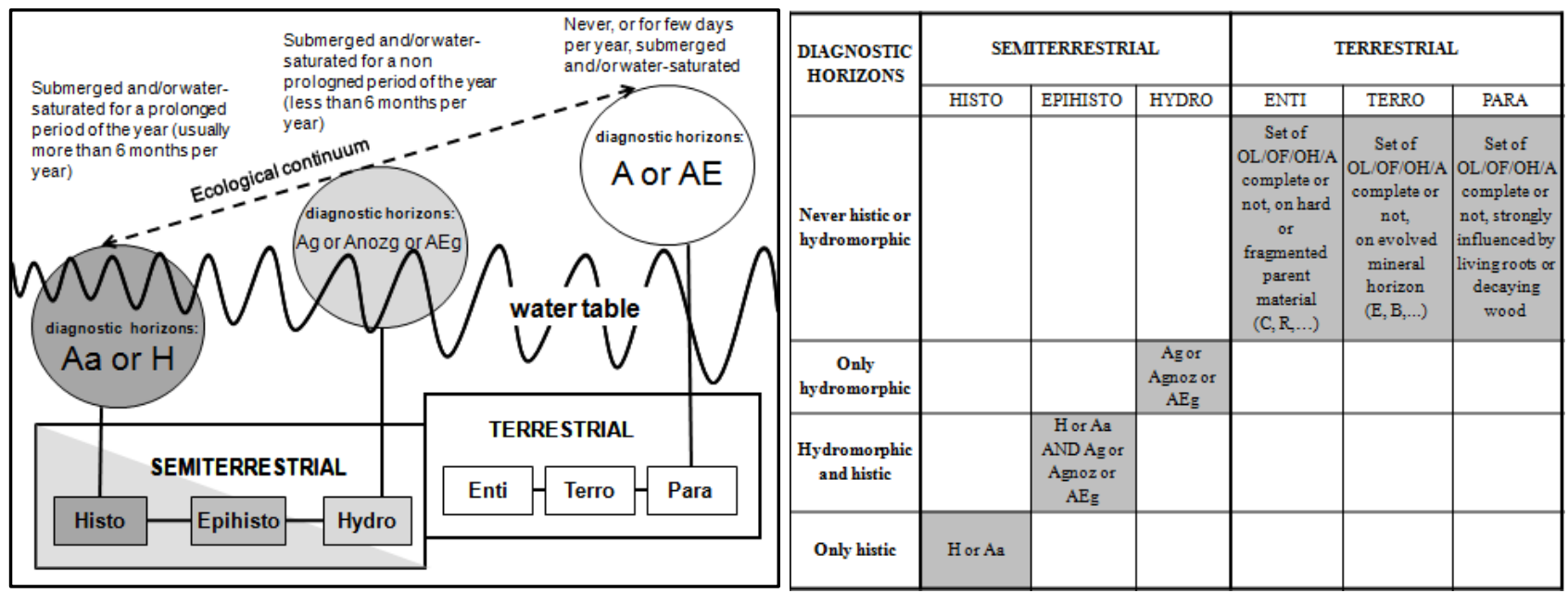

Fig. 5. Main subdivisions of Semiterrestrial and Terrestrial humus forms and their diagnostic horizons.

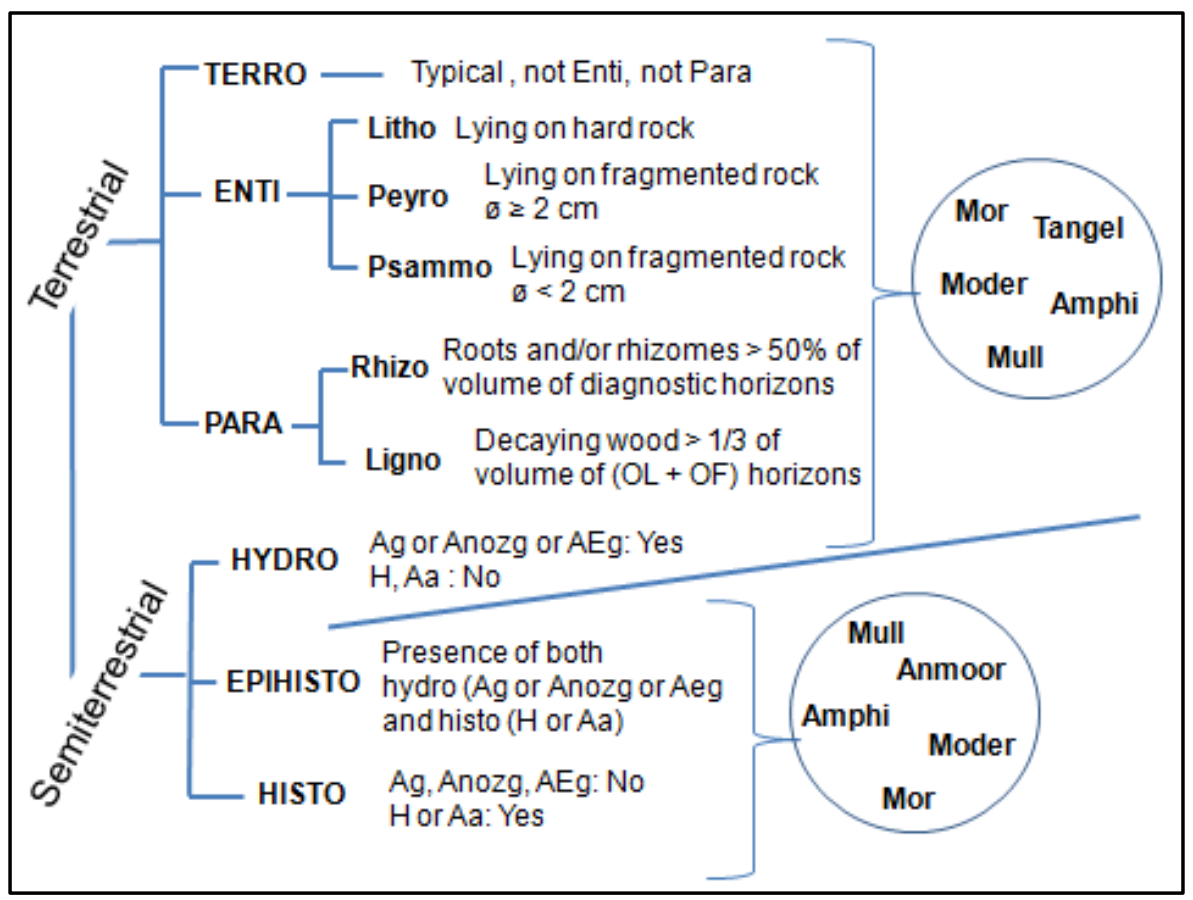

Fig. 6. The European tree of humus forms classification. The first dichotomy separates Terrestrial humus forms, which are never waterlogged or only for a few days per year, from Semiterrestrial humus forms which are seasonally waterlogged. Each of these main groups is subdivided in three secondary groups, one of them being typical of the main group (Terro for Terrestrial, Histo for Semiterrestrial humus forms), the other two being specialized or atypical forms. Among Terrestrial humus forms, Entiforms are initial forms, subdivided in turn according to substrate, and Paraforms are atypical, subdivided in turn according to the main building agent. Among Semiterrestrial humus forms, Hydroforms are transitional to Terrestrial humus forms and Epihisto are atypical. On the right two circles indicate main humus forms which can be found in both Terrestrial and Semiterrestrial groups. Note that these names correspond to morpho-functional types that can be found in both environments (Mull, Moder, Mor, Amphi) or not (Anmoor, Tangel) and are at least partly independent of the classification, as a reflection of diagnostic features of biological activity.

\subsubsection{Entiforms}

Entiforms are subdivided into Lithoforms, Peyroforms and Psammoforms according to the degree of fragmentation of the underlying rock (Fig. 6) and their five main references are characterized, as Terroforms, according to the sequence of diagnostic horizons.

\subsubsection{Paraforms}

Paraforms are subdivided into Rhizoforms and Lignoforms according to the plant material (roots or wood) which accumulates in the topsoil. As for the preceding units, they are subdivided into Tangel, Amphi, Mull, Moder and Mor secondary references.

\subsubsection{Vocabulary notes}

In the proposed classification, a terrestrial Mull can be a Terromull (typical form on 'normal' well-drained soil), an Entimull (lying directly on a rocky substrate) or a Paramull if subterranean parts of plants or wood dominate it, allowing a large array of poorly identified humus forms, with rarely encountered characters, to be classified. The words Mull, Moder, Mor, 
Amphi and Tangel without prefixes mean Terromull, Terromoder, Terromor, Terroamphi and Terrotangel, respectively. Note that the word used for every second level of Terroforms is unambiguous: Eumull and Leptoamphi, for instance, can only be Euterromull and Leptoterroamphi respectively; the prefix "terro" is unnecessary and never used for naming these second level units.

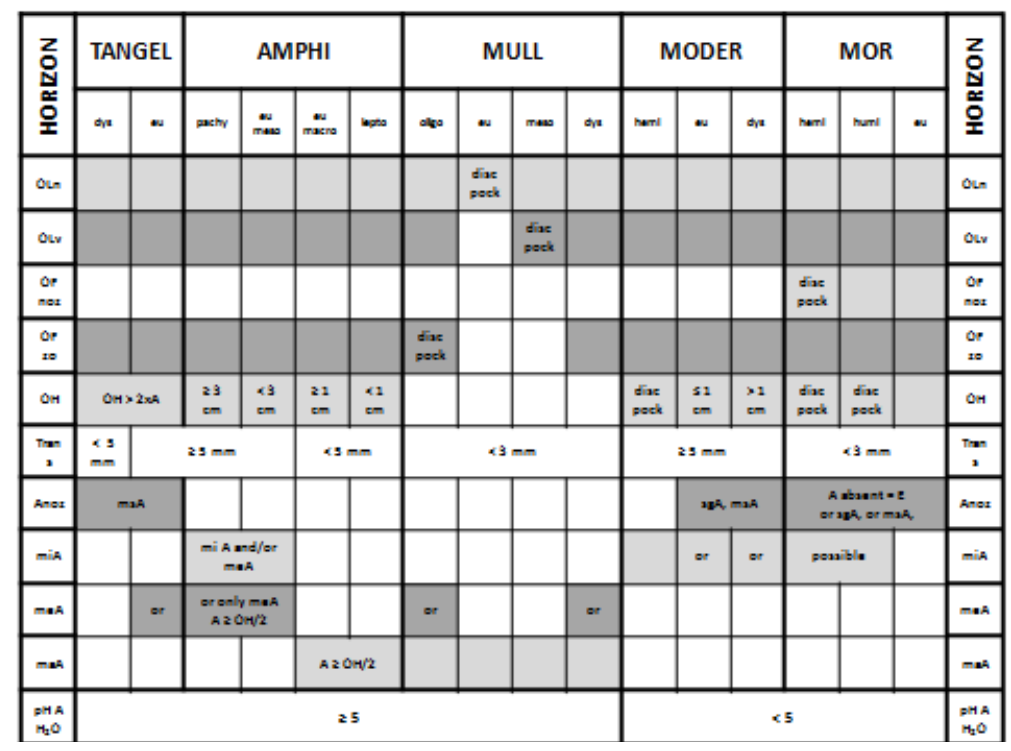

Fig. 7. Second level classification of Terroforms. Lines: diagnostic horizons, superposed as in a real topsoil profile. Columns: second level of classification (examples of Mull: eumull, mesomull, oligomull, dysmull). Mull is considered as central form, divided into sub-forms evolving on calcareous (left) or acid (right) substrates. The order of Mull sub-units could differ from the one marked in the table. In fact, all gradual series from more to less biologically active forms (eu $\rightarrow$ meso $\rightarrow$ oligo $\rightarrow$ dys) are possible as well under calcareous, neutral and siliceous soil/substrate influences.

\subsection{Semiterrestrial humus forms}

The Semiterrestrial humus forms correspond to the topsoil (organic and organo-mineral horizons) submerged and/or water-saturated for more than a few days per year. These conditions of anoxia delay the process of biodegradation and the thickness of organic layers may even increase to several metres. Only the first $40 \mathrm{~cm}$ of the topsoil are observed and analyzed in order to classify semiterrestrial humus forms, the underlying part of the profile corresponding to well-detected and described Histosols following methods proposed by the main international soil classifications (FAO, 2006; AFES, 2009; Soil Survey Staff, 2010). Definitions of semiterrestrial Mull, Moder, Amphi, Mor and Tangel differ from terrestrial definitions, the unaltered organic layers acting as parent material, while in terrestrial humus forms parent materials are mostly mineral. A specific Anmoor is also necessary for circumscribing particular conditions of periodic water saturation of the soil. The Semiterrestrial humus forms are subdivided into Histo-, Epihisto- and Hydroforms along a gradient from submerged anoxic soils to drained or infrequently water-saturated ones.

\subsubsection{Histoforms}

The most typical semiterrestrial forms are the Histoforms. They are submerged and/or water-saturated for a prolonged period of the year (usually more than 6 months). Peat develops at the top of the humus profile due to anaerobic conditions slowing down the biological transformation of organic matter. Selecting the right master diagnostic horizons, a few main references (Histomor, Histomoder, Histoamphi, Histomull and Anmoor) are distinguished in order to separate Histoforms along a gradient of increasing biodegradation rate. A second level of classification of each main reference is shown in Figure 8.

\subsubsection{Hydroforms}

In Hydroforms organic horizons are rarely submerged and the biotransformation of organic matter is relatively close to aerated conditions, with the same animals and products of their activities. However, organo-mineral horizons always show signs of periodic anoxia. In this first attempt at classifying Hydroforms, five main references (Hydromor, Hydrotangel, Hydromoder, Hydroamphi and Hydromull) have been defined without any second level of classification (Fig. 6). All Hydroforms except Hydromull are often submerged up to the base of the $\mathrm{OH}$ horizon and the transition between organic and organo-mineral horizons is often not sharp $(>5 \mathrm{~mm})$; tongues of coloured organic matter can dip into the soil from the top organic horizons. Investigations into Hydrotangel and Hydroamphi forms have never been published. They develop on calcareous soils or basic parent materials, unlike Hydromoder and Hydromor that are formed on acid substrates.

\subsubsection{Epihistoforms}

Epihistoforms are introduced for classifying initial or transitional semiterrestrial humus forms with organic horizons of both Histoforms and Hydroforms. Selecting the right master diagnostic horizons, a few main references (Epihistomor, Epihistomoder, Epihistoamphi, Epihistomull and Epihistoanmoor) have been distinguished in order to separate Epihistoforms along a gradient of increasing biodegradation (Fig 6). 


\subsubsection{Vocabulary notes}

In the proposed classification, a semiterrestrial Mull can be a Histomull (typical form on 'prolonged' water-saturated soil), a Hydromull ('rarely submerged but hydromorphic' topsoil), or an Epihistomull (atypical form, presence of both histo- and hydro- diagnostic horizons). Note that the word Anmoor identifies only semiterrestrial forms and that second level Histoforms are unambiguous: Euanmoor and Limimull, for instance, can only be Euhistoanmoor and Limihistomull respectively; the prefix "histo" is unnecessary for naming these second level units.

\begin{tabular}{|c|c|c|c|c|c|c|c|c|c|c|c|c|c|c|}
\hline \multirow{2}{*}{$\begin{array}{l}\text { Diagn. } \\
\text { horizon }\end{array}$} & \multicolumn{3}{|c|}{ ANMOOR } & \multicolumn{2}{|c|}{ MULL } & \multicolumn{3}{|c|}{ AMPHI } & \multicolumn{4}{|c|}{ MODER } & \multicolumn{2}{|c|}{ MOR } \\
\hline & eu & sapri & limi & limi & sapri & humi & mesi & fibri & sapri & humi & mesi & fibri & mesi & fibri \\
\hline & & & & & & & & & & & & & & \\
\hline \multicolumn{2}{|l|}{$\mathrm{Hf}$} & & & & & & & & & & & & & \\
\hline & & & & & & & & & & & & & & \\
\hline & & & & & & & & & & & & & & \\
\hline $\mathrm{Hm}$ & & & & & & & & & & & & & & \\
\hline & & & & & & & & & & & & & & \\
\hline \multicolumn{15}{|l|}{ Hszo } \\
\hline & & & & & & & & & & & & & & \\
\hline & & & & & & & & & & & & & & \\
\hline Hsnoz & & & & & & & & & & & & & & \\
\hline & & & & & gentas & & & & & & & & & \\
\hline & & & & & & & & & & & & & & \\
\hline \multicolumn{15}{|l|}{ Hsl } \\
\hline & & & & & & & & & & & & & & \\
\hline & & & & & & & & & & & & & & \\
\hline \multirow[t]{2}{*}{ Aa } & & & & gensth & & & & & & & & & & \\
\hline & & & & & & & & & & & & & & \\
\hline
\end{tabular}

Fig. 8. Second level classification of Histoforms. Lines: diagnostic horizons, superposed as in a real topsoil profile. Columns: second level classification (examples of Anmoor: Euanmoor, Saprianmoor, Limnianmoor). Note that the classification of Histoforms is based on both quality and thickness of each diagnostic horizon.

\section{Prospects for the use of the European classification of humus forms}

Many benefits can be expected from (i) a better characterization of humus forms, in particular for mapping and database purposes, (ii) a common language and vocabulary that could be accepted and used worldwide, (iii) a field instrument for the estimating the effects of global and local changes on soil C pools, (iv) a practical and conceptual tool for planning studies in soil biology, (v) a better knowledge of factors acting at the interface of soil, vegetation and climate.

The humus forms contain most of the soil organic carbon, plant and animal remains (entire, fragmented, more or less biodegraded bodies or organs) and organic molecules (exudates, humic acids, proteins,....) within organic and organomineral horizons (Batjes, 1996). The humus form is the seat of feed-back interactions, within the topsoil of a given local ecosystem, among roots, animals and associated biodegrader communities (Ehrenfeld et al., 2005). Changing the ecological frame (climate, parent material, human pressure, history...), the system evolves consequently into new biocenoses characterized by adapted humus forms (Ponge, 2003). The soil as carbon sink will be better understood if the spatial distribution of humus forms is taken into consideration when sampling the area (Sartori et al., 2004). It is thus strongly recommended to survey and sample thickness and composition of diagnostic horizons of each different humus form, and to elaborate models of spatial distribution of humus forms (Aberegg et al., 2009). An attempt to extend the system to the microscopic scale is underway and will be published as soon as possible.

\section{Acknowledgements}

The authors warmly acknowledge Alain Brêthes (Office National des Forêts, Boigny-sur-Bionne, France), Gabriele Broll (University of Vechta, Germany), Jean-Michel Gobat (University of Neuchatel, Switzerland), Jean-Jacques Brun (CEMAGREF, Saint Martin d'Hères, France), Gerhard Milbert (Geological Survey of North Rhine-Westphalia, Krefeld, Germany), Eckart Kolb (Technische Universität München, Dept. of Ecology/Forest Nutrition and Water Resources, Freising, Germany), Ugo Wolf (University of Florence, Dept. of Agronomy and Land Management, Florence, Italy), Lorenzo Frizzera and Paola Galvan (Centro di Ecologia Alpina, Fondazione Edmund Mach, Viote del Monte Bondone, Italy), Raimo Kolli (Estonian University of Life Sciences, Tartu, Estonia), Rainer Baritz (Federal Institute for Geosciences and Natural Resources, Hannover, Germany), Rolf Kemmers (Alterra, University and Research Centre, Wageningen, the Netherlands ), Andrea Vacca and Gianluca Serra (University of Cagliari, Dept. of Earth Sciences, Cagliari, Italy), Damien Banas (University of Nancy, Vandoeuvre-lès-Nancy, France), Adriano Garlato (ARPAV Servizio Osservatorio Suoli e Rifiuti, Treviso, Italy), Silvia Chersich (University of Pavia, Dept. of Earth Sciences, Pavia, Italy), Emil Klimo (Mende University of Agriculture and Forestry, Brno, Czech Republic), Roger Langohr (Research Institute for Nature and Forest, Geraardsbergen, Belgium) for their precious help in improving the manuscript.

The paper summarizes seven years of exchanges among members of the Humus Group (13 European countries). Their inputs contributed to the success of the synthesis of knowledge about humus forms. Thanks to everyone for their data, ideas, discussions and friendliness. In alphabetical surname order: Anna Andretta (Italy), Michael Aubert (France), Roland Baier (Germany), Rainer Baritz (Germany), Hans-Jörg Brauckmann (Germany), Fabrice Bureau (France), Paolo Carletti (Italy), Nathalie Cassagne (France), Lauric Cécillon (France), Giuseppe Concheri (Italy), Fausto Fontanella (Italy), Hannu Ilvesniemi (Finland), Erik Karltun (Sweden), Tomaz Kralj (Slovenia), Jarmila Lesna (Czech republic), Lars Lundin (Sweden), Erwin Meyer (Austria), Roberto Menardi (Italy), Lucio Montecchio (Italy), Serenella Nardi (Italy), Silvia Obber (Italy), Diego Pizzeghello (Italy), Eva Ritter (Denmark), Mirco Rodeghiero (Italy), Linda Scattolin (Italy), Roberto Secco 
(Italy), Jan Sevink (the Netherlands), Marija Grozeva Sokolovska (Bulgaria), Andrea Squartini (Italy), Elena Vendramin (Italy), Roberto Zampedri (Italy), Miglena Zhiyanki (Bulgaria).

\section{References}

Aberegg, I., Egli, M., Sartori, G. \& Purves, R. 2009. Modelling spatial distribution of soil types and characteristics in a high Alpine valley (Val di Sole). Studi Trentini di Scienze Naturali, 85, 39-50.

AFES 1995. Référentiel Pédologique 1995. INRA, Paris.

AFES 2009. Référentiel Pédologique 2008. Quae, Paris.

AK Humusformen 2004. Systematik der Humusformen, AK Humusformen der Deutschen Bodenkundlichen Gesellschaft [http://www.humusformen.de].

Babel, U. 1971. Gliederung und Beschreibung des Humusprofils in mitteleuropäschen Wäldern . Geoderma, 5, $297-324$.

Baize, D. \& Girard, M.C. 1998. A Sound Reference Base for Soils: the "Référentiel Pédologique". INRA, Paris.

Baritz, R. 2003. Humus forms in forests of the northern German lowlands. Schweizerbart, Stuttgart.

Batjes, N.H. 1996. Total carbon and nitrogen in the soils of the world. European Journal of Soil Science, 47, 151-63.

Broll, G., Brauckmann, H.J., Overesch, M., Junge, B., Erber, C., Milbert, G., Baize, D. \& Nachtergaele, F. 2006. Topsoil characterization: recommendations for revision and expansion of the FAO-draft (1998) with emphasis on humus forms and biological factors. Journal of Plant Nutrition and Soil Science, 169, 453-461.

Brunner, H., Nievergelt, J., Peyer, K., Weisskopf, P. \& Zihlmann, U. 2002. Klassifikation der Böden der Schweiz. FALReckenholz, Zürich.

Delecour, F. 1983. Les formes d'humus: identification et description. Les Naturalistes Belges, 64, 75-86.

Ehrenfeld, J.G., Ravit, B. \& Elgersma, K. 2005. Feedback in the plant-soil system. Annual Review of Environment and Resources, 30, 75-115.

FAO 2006. Guidelines for Soil Description, 4th edition. FAO, Rome.

Galvan, P., Scattolin, L., Ponge, J.F., Viola, F. \& Zanella, A. 2005. La forme di humus e la pedofauna. Interpretazione delle interrelazioni e chiavi di riconoscimento. Sherwood, 112, 33-39.

Green, R. N., Trowbridge, R. L. \& Klinka, K. 1993. Towards a taxonomic classification of humus forms. Forest Science Monographs, 29, 1-49.

Hartmann, F. 1944. Waldhumusformen. Zeitschrift für das Gesamte Forstwesen, 76, 39-70.

Hesselmann, H. 1926. Studier över barrskogens humustäcke, dess egenskaper och boroende av skogsvården. Meddelanden från Statens Skogsförsöksanstalt, 22, 169-552.

ISO 10390 2005. Soil Quality: Determination of $\mathrm{pH}$. International Organization for Standardization, Geneva.

IUSS Working Group WRB 2007. World Reference Base for Soil Resources 2006, first update 2007. World Soil Resources Reports 103. FAO, Rome.

Jabiol, B., Brêthes, A., Brun, J.J., Ponge, J.F., Toutain, F., Zanella, A., Aubert, M. \& Bureau, F. 2009. Typologie des formes d'humus forestières (sous climat tempéré). In: AFES 2009. Référentiel Pédologique 2008, pp. 327-355. Quae, Paris.

Jabiol, B., Brêthes, A., Ponge, J.F., Toutain, F. \& Brun, J.J. 2007. L'Humus sous Toutes ses Formes, $2 e$ édition revue et corrigée. ENGREF, Nancy.

Jabiol, B., Feller, C. \& Greve, M.H. 2005. Quand l'humus est à l'origine de la pédologie. 2. Avant et après Müller: évolution des conceptions sur la description et la typologie "des humus". Étude et Gestion des Sols, 12, 123-133.

Jabiol, B., Zanella, A., Englisch, M., Hager, H., Katzensteiner, K. \& de Waals, R. 2004. Towards a European classification of terrestrial humus forms. Eurosoil Congress, Freiburg, Germany, September 4-12, 2004.

Kubiëna, W.L. 1953. The Soils of Europe. Thomas Murby, London.

Müller, P.E. 1879. Studier over skovjord, som bidrag til skovdyrkningens teori: om bögemuld og bögemor paa sand og ler. Tidsskrift for Skovbrug, 3, 1-124.

Müller, P.E. 1884. Studier over skovjord, som bidrag til skovdyrkningens teori: om muld og mor i egeskove og paa heder. Tidsskrift for Skovbrug, 7, 1-232.

Müller, P.E. 1887. Studien über die Natürlichen Humusformen und deren Einwirkung auf Vegetation und Boden: mit Analytischen Belegen von C.F.A. Tuxen (1887). Springer, Berlin.

Müller, P.E. 1889. Recherches sur les formes naturelles de l'humus et leur influence sur la végétation et le sol. BergerLevrault, Paris.

Nestroy, O., Danneberg, O.H., Englisch, M., Gessl, A., Hager, H., Herzberger, E., Kilian, W., Nelhiebel, P., Pecina, E., Pehamberger, A., Schneider, W. \& Wagner, J. 2000. Systematische Gliederung der Boden Österreichs (Österreichische Bodensystematik 2000). Mitteilungen der Österreichischen Bodenkundlichen Gesellschaft, 60, 1 124.

Ponge, J.F. 2003. Humus forms in terrestrial ecosystems: a framework to biodiversity. Soil Biology and Biochemistry, 35, 935-945.

Sartori, G., Obber, S., Garlato, A., Vinci, I. \& Pocaterra, F. 2004. Factors controlling alpine humus forms distribution (Venetian Alps, Italy). Eurosoil Congress, Freiburg, Germany, September 4-12, 2004.

Schoeneberger, P.J., Wysocki, D.A., Benham, E.C., \& Broderson, W.D. 2002. Field Book for Describing and Sampling Soils, Version 2.0. Natural Resources Conservation Service, National Soil Survey Center, Lincoln.

Soil Survey Division Staff 1993. Soil Survey Manual. USDA Soil Conservation Service, Washington.

Soil Survey Staff. 2010. Keys to Soil Taxonomy, 11th ed. USDA Natural Resources Conservation Service, Washington.

Van Delft, S.J.P., de Waal R.W., Kemmers R, Mekkink P. \& Sevink, J. 2007. Field Guide of Humus Forms: Description 
and Classification of Humus Forms for Ecological Applications. Alterra, Wageningen.

Zanella, A., Jabiol, B., Ponge, J.F., Sartori, G., De Waal, R., Van Delft, B., Graefe, U., Cools, N., Katzensteiner, K., Hager, H., Englisch \& M., Brêthes, A. 2009. Towards a European humus forms reference base. Studi Trentini di Scienze Naturali, 85, 145-151.

Zanella A., Englisch M., Jabiol B., Katzensteiner K., de Waal R., Hager H., van Delft B., Graefe U., Brun J.J., Chersich S., Broll G., Kolb E., Baier R., Baritz R., Langohr R., Cools N., Wresowar M., Milbert G. \& Ponge J.F. 2006. Towards a common humus form classification, a first European approach: few generic top soil references as functional units. Poster presented at the 18th World Congress of Soil Science, Philadelphia, July 9-15, 2006.

Zanella, A., Tomasi, M., de Siena, C., Frizzera, L., Jabiol, B., Nicolini, G., Sartori, G., Calabrese, M.S., Mancabelli, A., Nardi, S., Pizzeghello, D. \& Odasso, M. 2001. Humus Forestali. Centro di Ecologia Alpina, Trento. 